\title{
Evaluation of the biodiversity and stabilization of the soil after the fixating of the dunes by Retama retam Webb., Tamarix gallica L. and Tamarix aphylla (L.) Karst in the dunes cordon of El-Mesrane (W. Djelfa) in Algeria
}

\author{
Nassima Guerrache*, Saida Akkouche and Leila Kadik \\ Laboratory of Plant Ecology, Houari Boumediène Bab Elzzouar University, Algeria.
}

Received 17 January, 2014; Accepted 16 April, 2014

\begin{abstract}
Our study of the biodiversity of the vegetation and the stability of the soil surface at the levels of the dunes fixed by Retama retam Webb., Tamarix gallica L., Tamarix aphylla (L.) Karst and the natural fixation in the two experimental projects of the dunes fixation in Zahrez Gharbi of El-Mesrane region (W. Djelfa) shows that the dunes fixed by $T$. gallica and $T$. aphylla represent an important diversity with 57 species, 36 species in the dunes fixed by $R$. retam Webb. and T. aphylla (L.) Karst and a significant diversity of 24 species at the levels of the dunes naturally fixed. The Shannon weaver -index $\left(H^{\prime}\right)$ registered on the vegetation of the dunes fixed by $T$. gallica $L$. and $T$. aphylla (L.). Karst is of $H$ ' $=3.12$; it is 2.61 at the levels of dunes fixed by R. retam Webb. and T. aphylla (L.). Karst, It achieved a 2.18 on the vegetation of the natural regeneration of $R$. retam Webb and sandy plants. On the qualitative plan, the distribution of the biologic types is marked by the dominance of the therophytes of the flora. The multidimensional treatment demonstrated that the moisture, the fertility and the soil stability are the ecological factors responsible for the composition and the repartition of the vegetation in the several studied dunes which demonstrates that there is noticeable dunes stability through the mechanical and biological treatment realized on these dunes.
\end{abstract}

Key words: Zahrez Gharbi, desertification, El-Mesrane, fixation, dunes, cordon.

\section{INTRODUCTION}

The dune cordon of Djelfa -Boussaâda is considered as a major topographical element at the level of the Zahrez basin (Gharbi and chergui W Djelfa) and constitutes a permanent menace for the surrounding ecosystems. Under the wind dynamic, the free sands colonize the neighboring zones (farm land, tracks and infrastructures) considered as the most visible phenomenon of desertification, the dunes mobility cause significant economical and social repercussions.

The different fixation works on dunes led by the National Institute of the Forest Researches (NIFR) since 1982, in the two experimental projects on the dune 


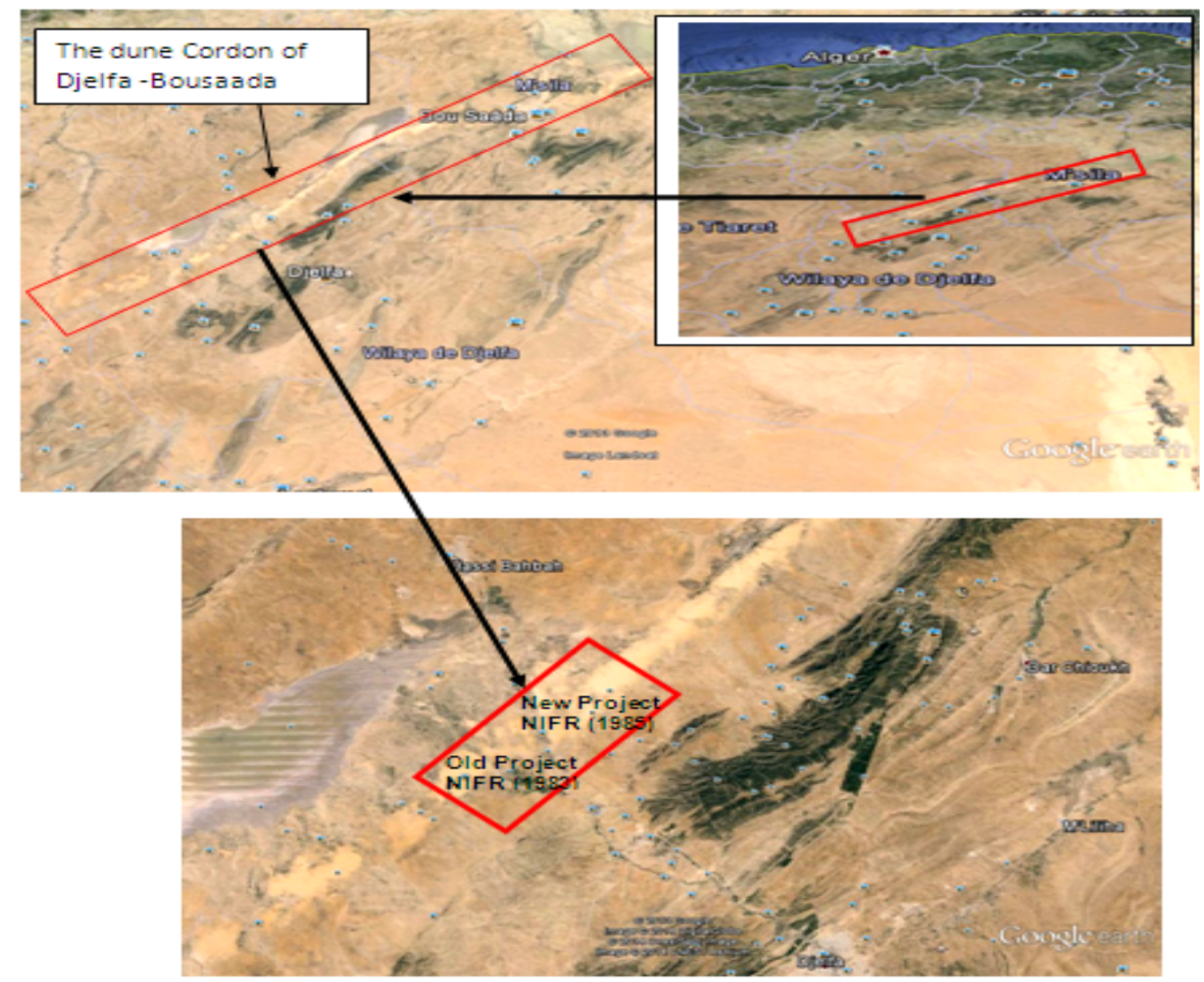

Figure 1. Location of the fixation projects experimental of the dunes on the dune cordon of Djelfa Bousaada.

cordon of Zahrez Gharbi at the area called El-Mesrane (W. Djelfa) consist in testing the different mechanical and biological dunes fixation technically and in comparing their resistance to the environment conditions, as well as their efficiency to reach a stabilization model that is secure and economical. However, consequently to these dunes fixation studies, the current necessity is to establish a qualitative and quantitative evaluation of the different experienced operations. Many studies to have been achieved in the dune cordon of El Mesrane (W. Djelfa) in order to know and inquire of the reaction and efficiency of the different alive and inert materials, introduced at an experimental level on the lively dunes. We cite as an example, the Makhlouf works 1992 on the sedimentologic studies of the sands of the dunes cordon in the Zahrez Gharbi basin (Djelfa) Chouial et al. (2000) which have proved the Algerian experience in the area of mechanical and biological fixation of the windmill formations such as the case of the experimental project of Elmesrane.

The objective of our current research is to achieve a quantitative and qualitative (phytoecologic) of the vegetation and an evaluation of the stabilization of the soil's surface of the dunes fixed by Retama retam Webb.,
Tamarix gallica L. and T. aphylla (L.) Karst in the experimented spots at the level of the dune cordon of Elmesrane.

\section{Description of the studied area}

\section{Geographic situation}

The studied area is situated in the dune cordon level according to Pouget (1980); this area is part of the Zahrez Gharbi basin in the high south plain of Algeria. Our studied area called El-Mesrane at $35 \mathrm{~km}$ of the north of Djelfa Town; it represents a middle altitude of $860 \mathrm{~m}$ which its geographic coordinates are: Longitude: $3^{\circ} 00$ and $3^{\circ} 03 \mathrm{E}$ and Latitude: $34^{\circ} 34^{\prime}$ and $34^{\circ} 36 \mathrm{~N}$.

The specific studied area includes the different fixed dunes in 1983 by the NIFR in the fixation experimental projects of the dunes (Figure 1).

\section{Geology and geomorphology}

The dune cordon is a recent geological formation which 


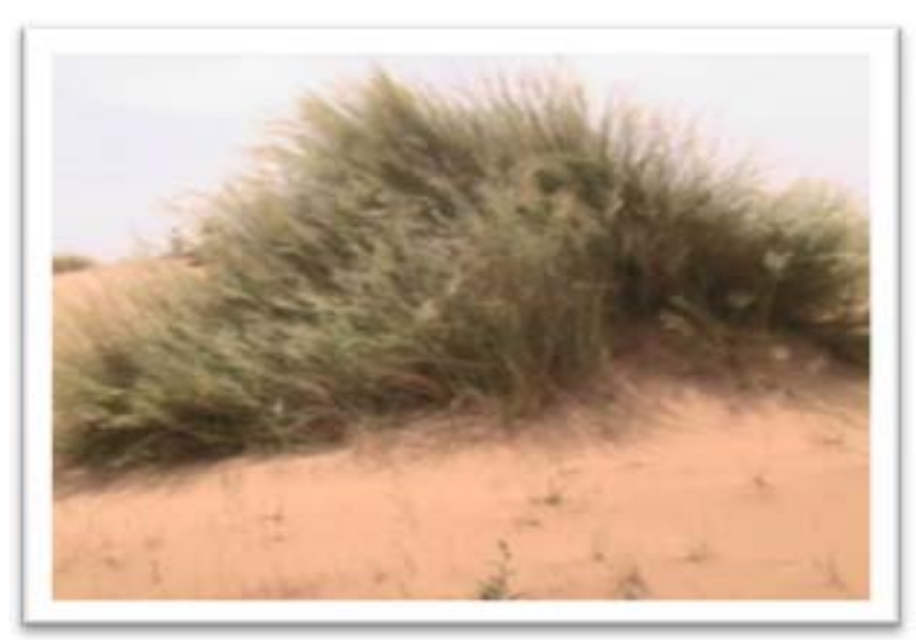

Figure 2. Micro-dune fixed by Aristida pungens Photo taken by Guerrache, March 2013.

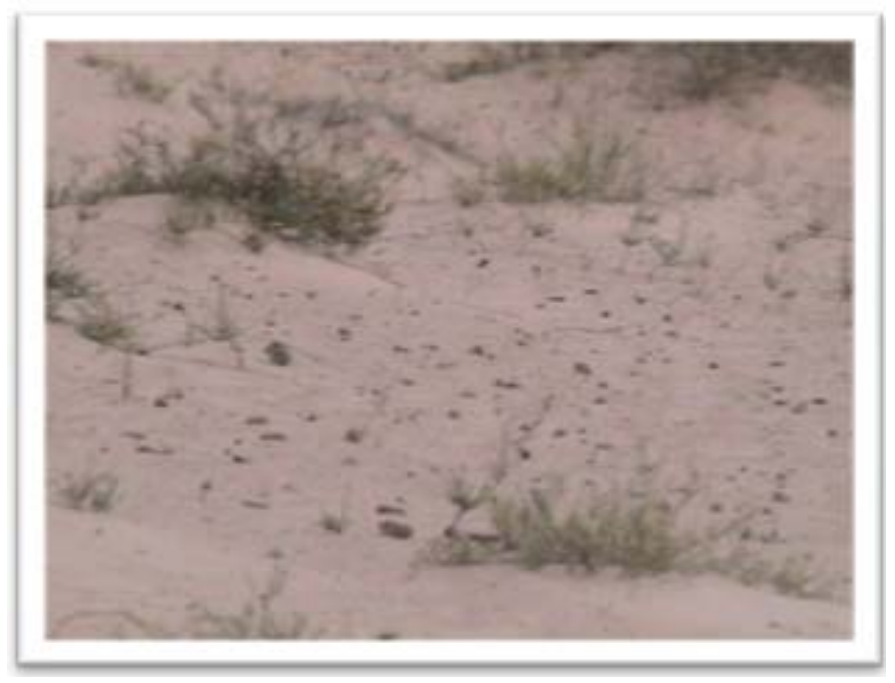

Figure 3. Nebkas formed by Saccocalyx satureioides Photo taken by Guerrache, March 2013).

appears at the end of the tertiary and the beginning of the quaternary, coming from the soft rocks (marlstone and red clay) which have been extracted by the erosion of the mountain as well as the presence of salt Limestone Gypsum and soluble salts) that have many effects on the composition of waters either underground or superficial ones (Figures 2 and 3 ).

\section{Pedology}

According to Pouget (1980), the color of the sands varies from the red (5 YR 5/6-6/6) to the white (IO YR 8/1) while passing through the yellow (7,5 YR 6/6 à 6/4). As for most windmill formation of this kind, the granulometric fractions inferior to $50 \mu$ (clays and thin Silt) are practically absent (Figure 4a, b, c, d).

\section{Vegetation}

The dune cordon is characterized by sandy vegetation and phreatophyte (Figure 5a, b) (Tamarix sp, Imperata cylindrica, Phragmites communis). We can distinguish several groups: To the north: the principal Nebkas are colonized by the following groups: Tamarix and salicornes, sparte (Lygeum spartum, Artemisia campestris, Drinn (Aristida pungens), Saccocalyx satureioides. Between the Zahrez; the crassulescentes steppes to salicornia arabica and Suaeda mollis are dominant to the south -west of the dune cordon on the alluvial soils: Steppes at white Artemisia (Artemisia herba alba), sparte ( $L$. spartum), A. campestris, as well as cereal cultures between these different formations. The species used for the biological fixation at the level of ElMesrane dunes are: Atriplex halimus, Atriplex canescens, Atriplex nummularia, Acacia cyanophylla, Acacia cyclops, Elaeagnus angustifolia, Gleditsia triacanthos L., Lycium arabicum, Medicago arborea, Opuntia ficus indica, Pistacia atlantica Desf, Prosopis juliflora, R. retam, T. aphylla, T. gallica.

\section{Bioclimate}

Our studied area presents an accentuated arid tendency of a semi arid inferior type with a fresh winter characterized by a long dried season going of May to October undergoes the geographic situation between the influence of the south and those of the Mediterranean to the north (Kaabeche, 1997). The climate is rigorous, extreme and uncertain with an annual rainfall range feeble and irregular; it is evaluated at $326.91 \mathrm{~mm} / \mathrm{year}$. And the average temperature records the maximum in July $26.83^{\circ} \mathrm{C}$ and the minimum in January $4.76^{\circ} \mathrm{C}$. Moreover, the winds are always violent consequently the vegetation cannot install without an adequate protection system.

\section{METHODOLOGY}

\section{The sampling}

We achieved two studies, quantitative and qualitative (phytoecological) the sampling took place during the 2008, 2009 and 2012 spring period, a period in which all the spring species are represented.

\section{Quantitative inventory (linear Statement)}

The linear statement is considered as an efficient means to study the evolution of the vegetation cover when it involves a permanent 


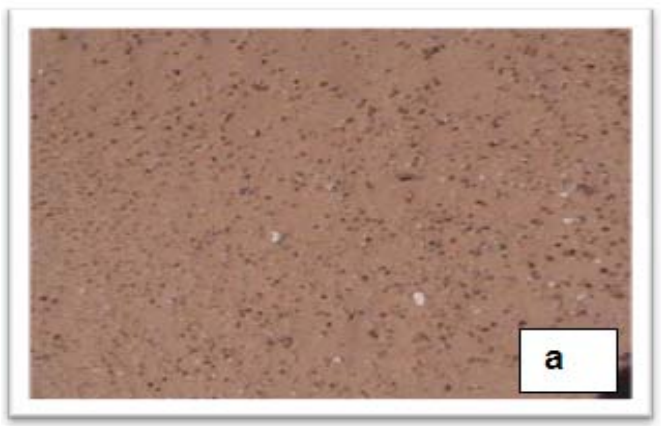

More unrefined sands of fluviatile origin resulting from the deflation of the beds of wadi or alluvial manurings
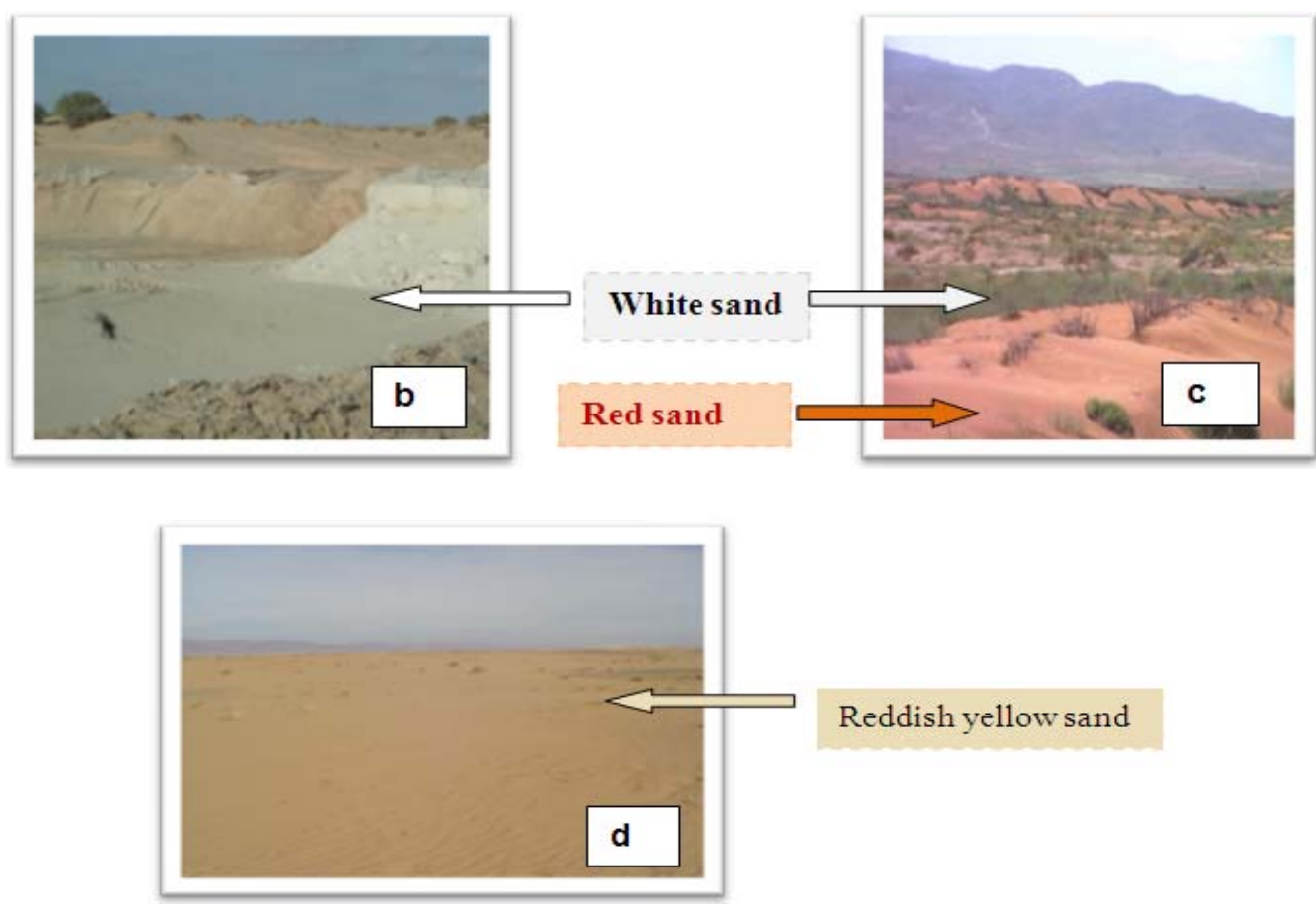

Figure $4(a, b, c, d)$. Texture and color of the sand of the wind formations Photo taken by Guerrache, March 2013).
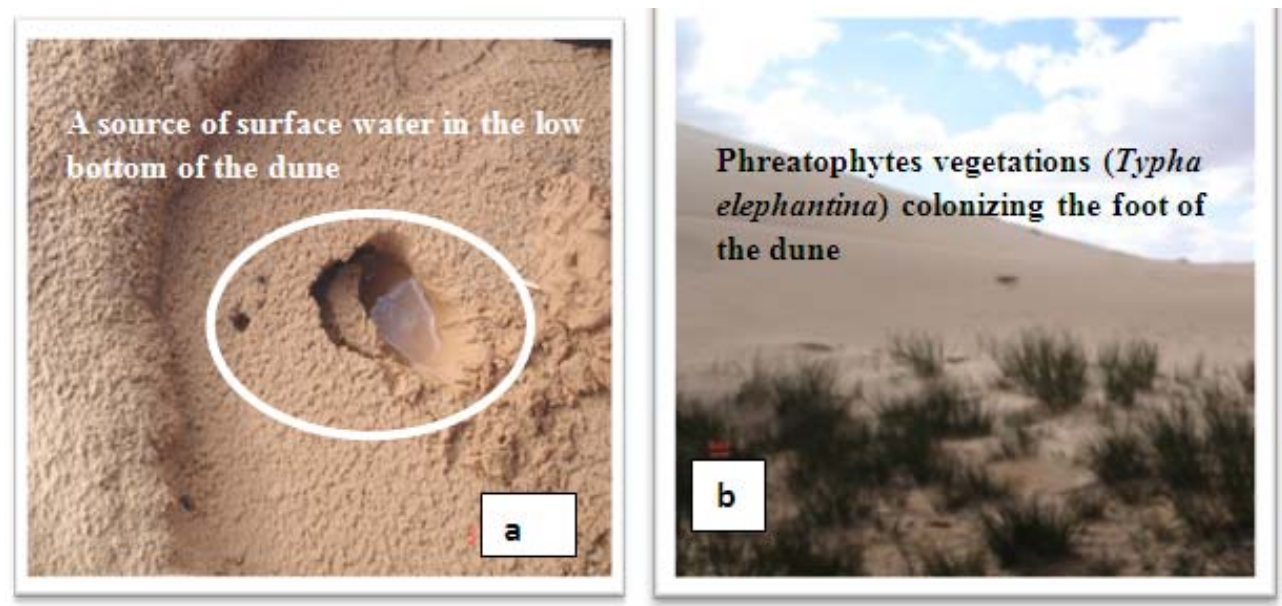

Figure $5(\mathbf{a}, \mathbf{b})$. Photos showing the importance of groundwater of the dune cordon of Zahrez Photo taken by Guerrache, March 2013). 
line Gounot (1969), Aidoud (1983), a reading can be done every 10 $\mathrm{cm}$ long and $10 \mathrm{~m}$ line and materialized by a graduated ribbon extended above the vegetation. This linear method permits to provide specific data related to the vegetation and the characteristics of the surface that allow evaluating:

(a) The global recovery of the vegetation (GR): Expressed in percentage is calculated as follow:

$$
\mathrm{GR} \%=100 \times \frac{\mathrm{Nv}}{\mathrm{N}}=100 \times \frac{N-N w v}{N}
$$

$\mathrm{N} v=$ number of points of vegetation; $\mathrm{N}=$ Number of points of reading (100 points); Nwv = number of points without vegetation.

(b) The specific frequency (SF) of a species: Allows to appreciate the place of the species "i" in the occupation of the total space of the vegetation:

$\mathrm{SFi}=\mathrm{ni} / \mathrm{N}$

$\mathrm{ni}=$ number of the species "i"; $\mathrm{N}=$ the sampled surface.

(c) The specific contribution (SC): Allows to estimate the contribution of the species "i" in the whole of the studied species:

$$
\mathrm{Csi}=\mathrm{SFi} / \sum \mathrm{SFi}
$$

The specific frequency (SF) of the species "i".

\section{Qualitative inventory (phytoecological)}

On the different picked dunes, we have delimited the area by $32 \mathrm{~m}^{2}$. It is the most adequate surface for the study of those dunes ecosystems dominated by the therophytes. 86 statements were achieved and every statement contains floristic and ecological data. The floristic data are represented through a list on which are mentioned all the identified species in the sampling area. Every species has abundance -dominances coefficient according to Braun-Blanquet scale 1959 and vegetal formation type characterized according to lonesco and Sauvage (1962).

\section{Analysis and data processing}

\section{Analysis statistic}

According to the number of data, 86 statements and 68 species were used to estimate multivariate analysis; factorial analysis of correspondence (FAC) and the ascendant hierarchic classification (AHC) whereas for the treatment of the floristic data, the software was utilized of version 5 statistica.

\section{Qualitative and quantitative evaluation of the biodiversity}

Biological diversity consequently made it possible for us to study the biological comeback after the dune stability. The taxons composing the different groups of the individualized vegetation were characterized by:

a) Their taxonomic diversity: This was realized from the flora of Algeria Quezel and Santa (1962-1963), the flora of Sahara (Ozenda, 1977), the flora and the vegetation of Sahara (Ozenda, 1991).

b) Biologically raw and real: The biological types listed in the database Raunkiaer (1934) Amended by Ellenberg and MullerDombois (1967) were used. c) The specific diversity, index of Shannon H': This was calculated from the (SC) generally measured by means of lines:

$\mathrm{H}^{\prime}=-\Sigma(\mathrm{ni} / \mathrm{N}) \times \log _{2}(\mathrm{ni} / \mathrm{N})$

$\mathrm{Ni}$ : Number of individuals of a species, i going of 1 in $S$ (total number of species).

$\mathrm{N}$ : Total number of individuals.

This index values was between 0 and 5 bits per individuals (Frontier, 1983).

d) Equitability (E): Represents the report between the specific diversity of theoretical maximal Shannon and the logarithm of specific wealth of the sample (Frontier, 1983):

$\mathrm{E}=\mathrm{H}^{\prime} / \mathrm{H}_{\text {max }}^{\prime}$ avec $\mathrm{H}_{\text {max }}^{\prime}=\log _{2} \mathrm{~S}$,

S: Specific wealth.

(d) The frequencies rows diagrams: Frontier and Pichod-Viale (1998) presented a detailed overview of the diversity because their speeds vary according to the specific diversity.

\section{RESULTS AND DISCUSSION}

Identification of the vegetal groups and their floristic and ecological characteristics

The examination of the projection of the points statements of the AFC statements-species (Figures 6,7 and 8) allowed us to identify the lots of the similar statements, this means the principal vegetal groups. The dendrogram analysis obtained permitted the division of the whole statements into two principal classes (Figure $6)$ :

Class A: It includes the achieved statements in the dunes already fixed by R. retam Webb., T. gallica L., T. aphylla (L.) Karst. This class is subdivided into two groups:

Group 1: It is formed by the achieved statements already fixed essentially by $T$. gallica L., $T$. aphylla (L.) Karst.

Group 2: It is formed by the achieved statements already fixed by $R$. retam Webb. and T. aphylla (L.) Karst that is localized in the depression.

Class B: Represented by one unique Group (3) formed by the achieved statements in the dunes recently fixed with the natural regeneration of $R$. retam Webb. and sandy plants.

\section{Ecological signification of the factorial axes}

\section{Factorial maps of the statements-species}

The factorial plans (1-2) Figures 7 and 8 illustrate three distinct and well individualized groups:

Group 1: It is characterized by the statements of the dunes fixed by $T$. gallica L., T. aphylla (L.) Karst with a dominant exposition (North) at different toposequences with a middle recovering of the vegetation of $35 \%$. This group represents vegetal species relatively demanding 


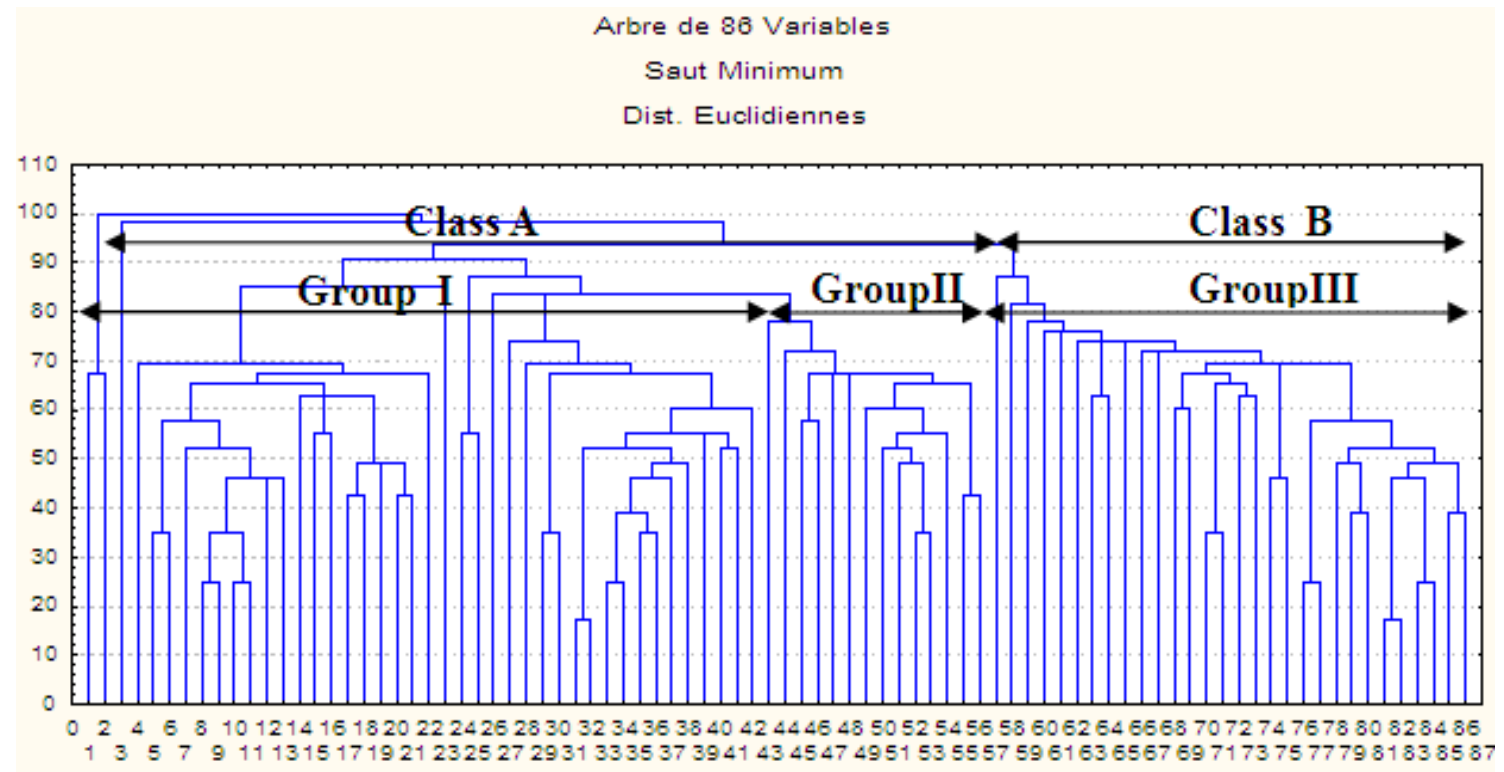

Figure 6. Ascending hierarchical classification of 86 statements.

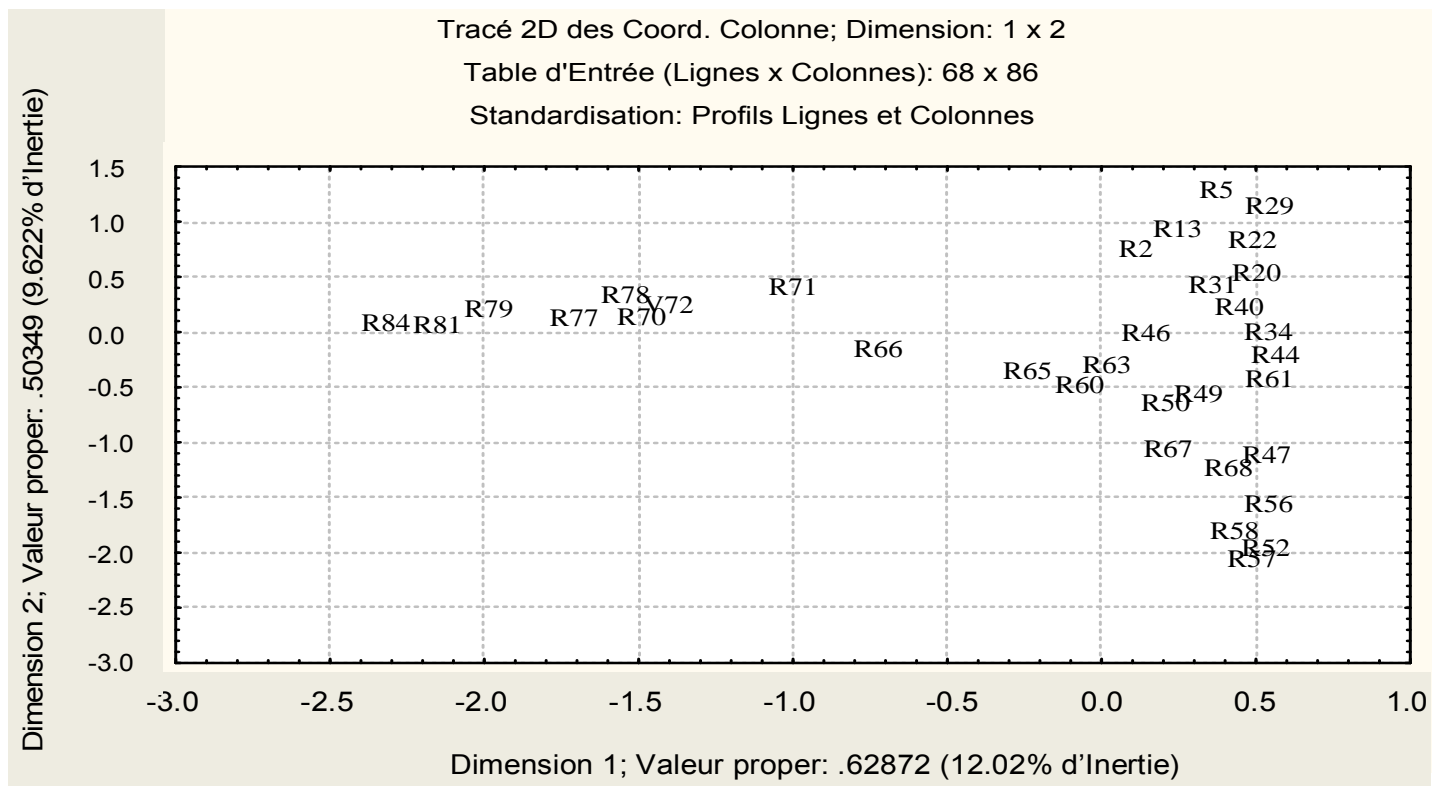

Figure 7. Factorial statements of the distribution along the axes 1 and 2 .

such as a species of the families of the compounds and grasses for example Paronychia argentea, Rumex bucephalophorus L. colonize the dry sandy areas, Atractylis carduus, Ifloga spicata (Sandy), Bassia muricata, Hordeum murinum, Galactites tomentosa, Lolium rigidum, Herniaria fontanesii, T. gallica, Schismus barbatus, Bromus sterilis, those species colonize the dunes already fixed in time. According to Ozenda (1982) $L$. rigidum, $B$. sterilis, $H$. murinum, $S$. barbatus $G$. tomentosa, B. muricata, T. gallica and T. aphylla characterized well the sandy area.

Group 2: Includes the dunes statements fixed by $R$. retam Webb. and $T$. aphylla (L.) Karst with a south dominant exposure where all the toposequences are presented except for the statement of $T$. aphylla (L.) Karst which is just in the depression that has a middle recovering of vegetation of $55 \%$. This group is marked by 


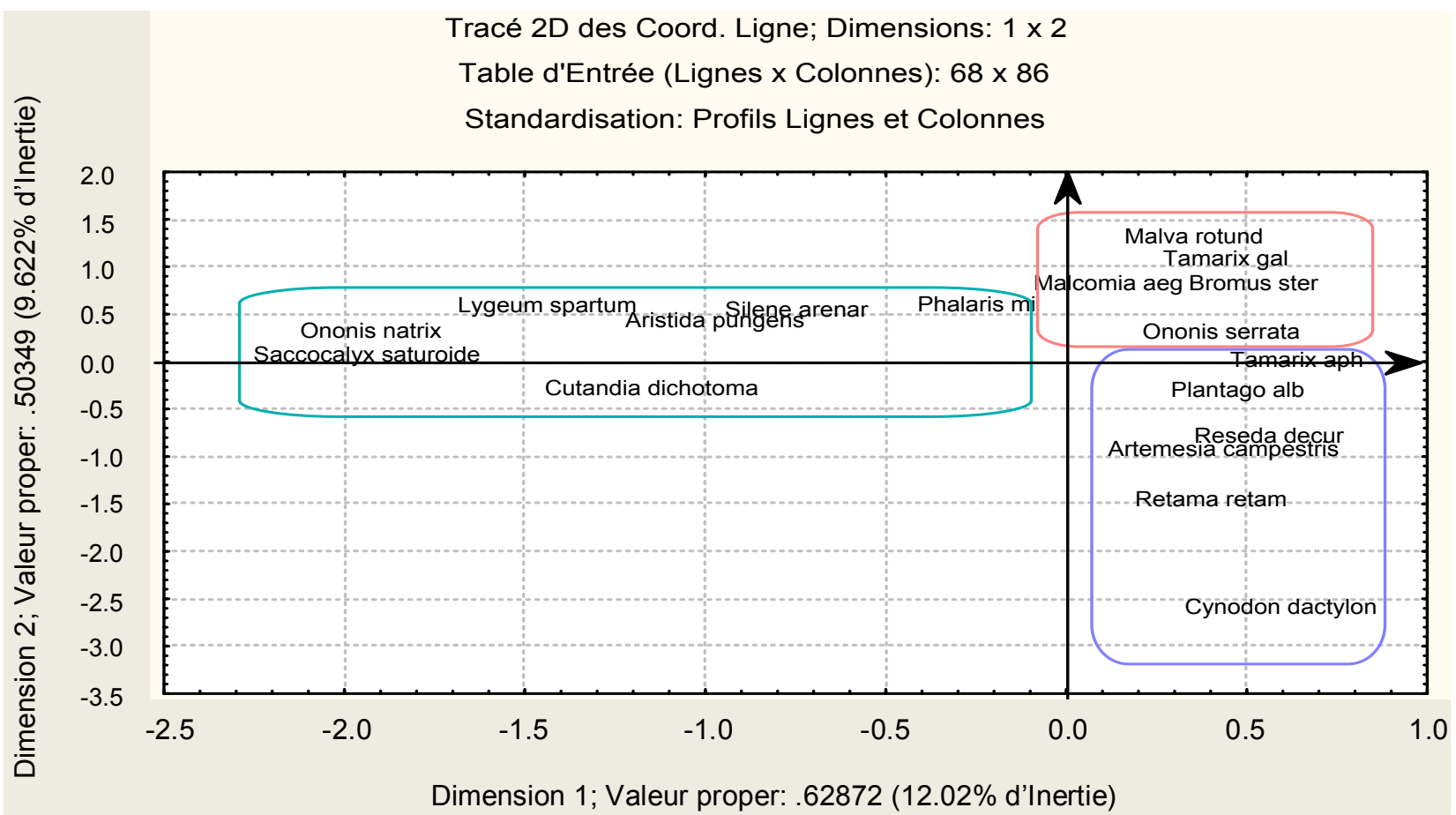

Figure 8. Factorial species of the distribution along axes 1 and 2 .

the presence of the following species $R$. retam, Plantago albicans Artemesia campestris, $M$. aegyptiaca and Launaea resedifolia. Eruca vesicaria, Scabiosa arenaria, T. aphylla, Reseda decursiva, P. albicans, R. retam.

According to Ozenda (1982) $P$. albicans is a frequent species in the consolidated sandy area, but Pouget (1980) characterizes it as a species consisting of a simple sandy veil at a surface of an underlying soil of any nature but Djebaili (1984) evokes this species in the alliance of $A$. herba alba and $P$. albicans colonizing the non salty depression and the soils are generally muddy. According to killian (1948), T. aphylla developed in the bed of the wadi where the layer of sand keeps humidity in the depth.

Group 3: Includes the statements of the dune recently fixed by the natural regeneration of $R$. retam and those which are not fixed yet and submitting the influence of the fixation with a south dominate exposure according to the different toposequences with a very weak recovering of the vegetation. There is a noticeable abundance of vegetal species well adapted to these areas: sandy species such as $A$. pungens, Euphorbia guyoniana, $S$. satureioides Ononis natrix, Pseuderucaria teretifolia Pouget (1979), Ozenda (1982). A. pungens, Cutandia dichotoma, Pseuderucarea teritifolea, Cynodo dactylon and Euphorbia colonize the dunes recently or not yet fixed.

According to Maire (1926), the sandy grounds of the highlands of the Sahara are occupied by the association to Drinn (A. pungens) in addition to these plants, we can find some nano-phanerophytes as $R$. retam, Saccocalyx satureoides, E. guyoniana, Thymelaea micrphylla, A. campestris and some are Hemicryptophytes such as Launea reseifolia, Onopordon arenarium and $M$. aegyptiaca.

The ecological significance of factorial axes will consequently be like this:

i. Axis 1 illustrates the evolution of the stability of the dune field: A fixed sandy soil, consolidated and frequented by relatively demanding species (positive part of Axis 1) is opposed to soil not yet stabilized, more or less mobile and colonized by sandy plants (negative part of Axis 1).

ii. Axis 2 denotes the dampness of the sandy soil and the fertility of the field in north exposure where we have the presence of species relatively water demanding such as $B$. sterilis, L. rigidum, T. gallica and T. aphylla (positive part of Axis 2) instead of other species enough resistant to the drought, well adapted to the arid conditions of those types of biotope and frequenting the south exposure such as Retam retam and $A$. campestris.

\section{Evaluation of the biodiversity}

\section{Systematic diversity}

At the level of the dunes fixed by T. gallica (L.) and $T$. 


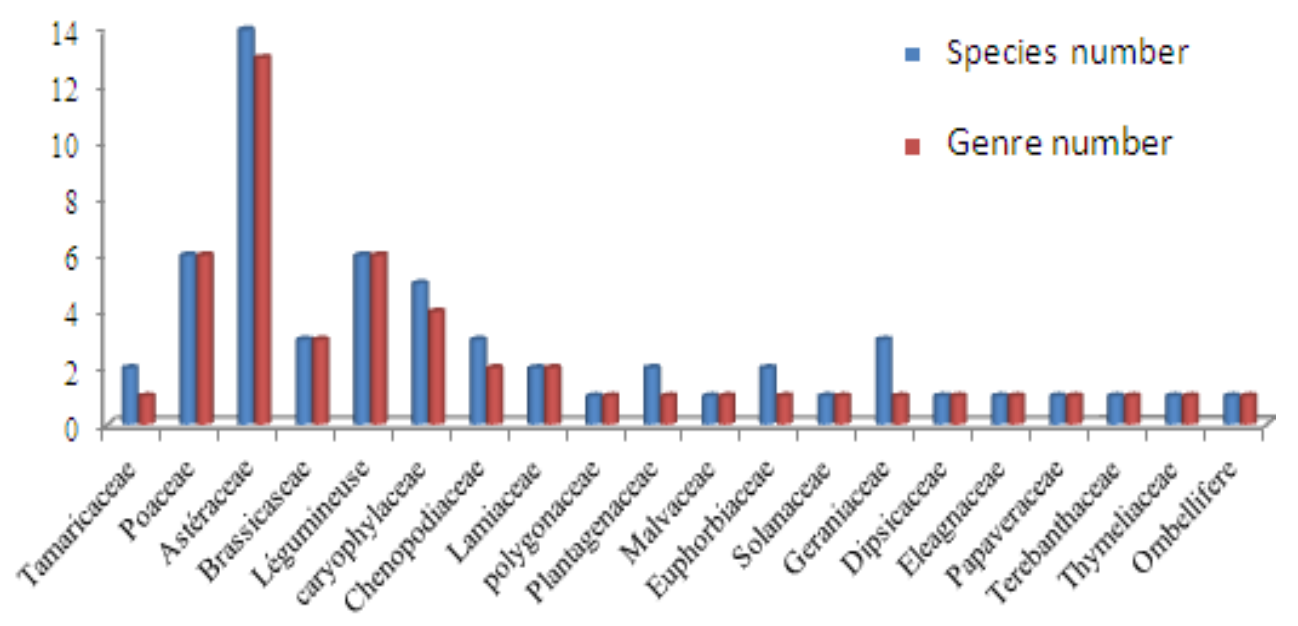

Figure 9. The diversity taxonomic of the group1 (Number of family and genre).

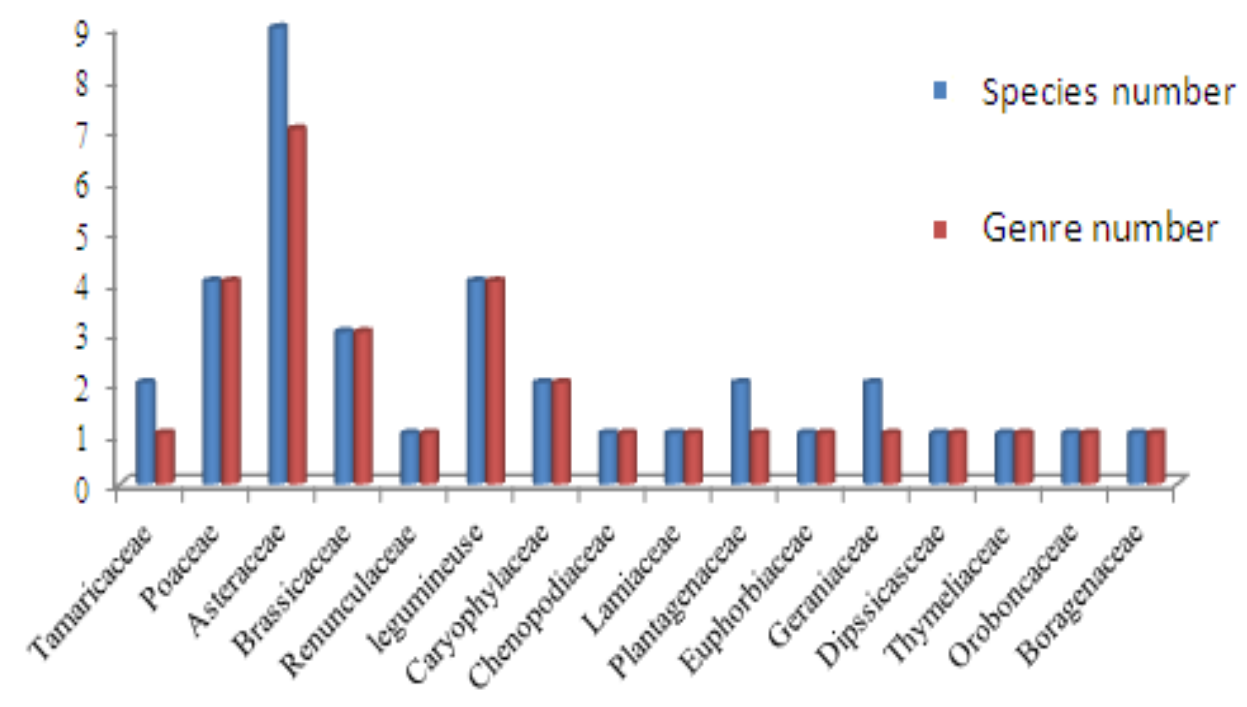

Figure 10. The diversity taxonomic of the group 2 (Number of family and genre).

aphylla (L.) Karst (Group 1), we counted 20 families, 49 genres and 57 species. Figure 9 shows the best families represented on the specific and generic plan which are the asteraceae (13 genres and 14 species) followed by the fabaceae (leguminous) and the poaceae (6 genres and 6 species), a feeble participation of the brassicaceae, chenopodiaceae and geraniacea ( 3 genres for each and 3,2 and 1 species, respectively).

The tamaricaceae, lamiaceae, plantagenaceae and euphorbiacea are represented just by 2 species in which majority is monogenetic, exceptionally for the lamiaceae, the other families are monogeneric and monospecific.

In Group 2, the analysis of the floristic composition of the fixed dunes by Retam retam Webb and T. aphylla (L.) Karst permitted the identification of 16 families, 30 genres and 36 species. The dominant families are the asteraceae (4 genres and 9 species), the fabaceae and the poaceae ( 4 genres, 4 species) then the brassicaseae (3 species and a monogeneric) followed by the tamaricaceae, caryophylaceae, plantagenaceae and geraniaceae present 2 species and only one genre, 9 families are monogeneric (Figure 10) group of natural fixation and the dune submitting the influence.

In Group 3, we counted just 9 families divided into 23 genres and 24 species. The best represented families on the generic and specific plan are always the asteraceae ( 8 genres and 8 species) followed by the fabaceae (3 genres, 3 species) then, the poaceae and the cayophylaceae (3 genres and 3 species), next, the plantagenaceae ( 2 genres and a monospecific). This 


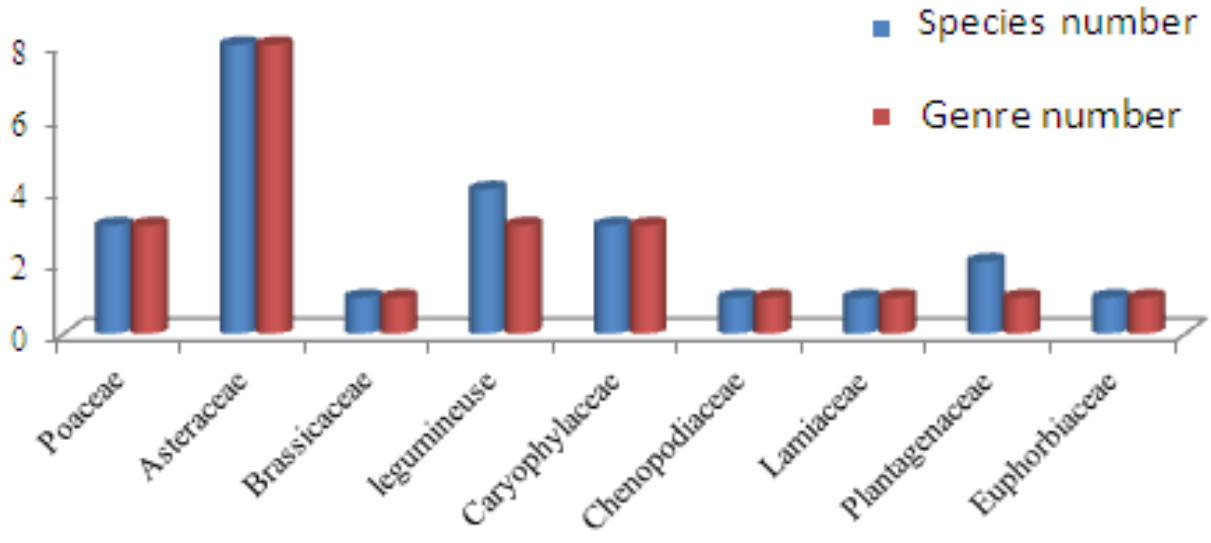

Figure 11. The diversity taxonomic of the group 3 (Number of family and genre).

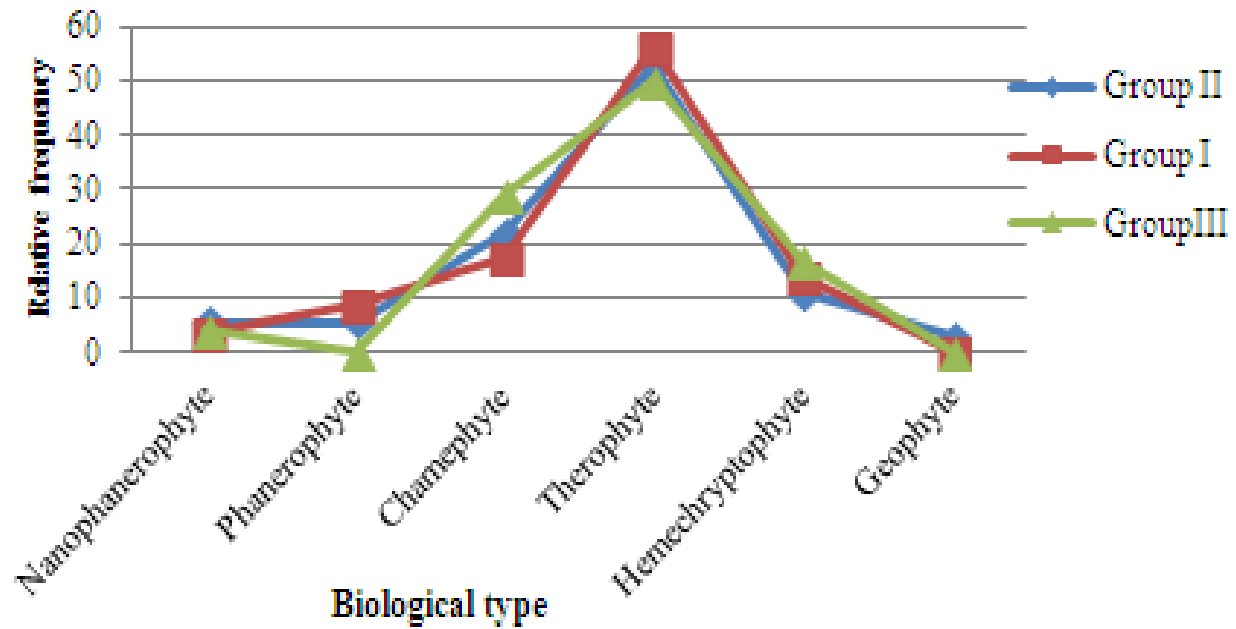

Figure 12. Raw biological spectrum of three groups.

group is also characterized by the presence of 4 monogeneric and monospecific families (Figure 11).

The flora analysis of three vegetal groups defined in the dunes cordon (Figures 5, 6 and 7) shows that these group have richness in families, genre and varied species, the group of the dunes fixed by $T$. gallica and $T$. aphylla (L.) Karst is the richest whereas Group 3 of the naturally fixed dunes and submitting the fixation influence is the poorest. The best represented families on the generic and specific plan in the three groups are: the Asteraceae, the fabaceae and the poaceae.

\section{Biological type}

\section{Raw spectrum}

The analysis of the distribution of the biological types
(Figure 12) reveals the neat dominance of the therophytes $56.14 \%$ in Group $1,52.77 \%$ and $50 \%$. In Groups 2 and 3, respectively followed by the chameaphytes that is important in Group 3 with $29.16 \%$, $22.22 \%$ in Group 1 and 17, 54\% in Group 2 then the hemicryptophytes that represents as well as relatively significant rate of $16.66,14.03$ and $11.11 \%$ in Groups 3, 2 and 1 , respectively.

Whereas for phanerophytes that occupy the fourth positions of $8.66 \%$ in the dunes fixed by $T$. gallica and $T$. aphylla (L.) Karst (Group 1). Followed by the nanophanerophytes with $3.50 \%$ and share the position with the nanophanerophytes $5.55 \%$ for each one in the dunes fixed by $T$. aphylla (L.) Karst and Retam retam Webb. (Group 2) followed by the geophytes that come in the last position with a very feeble presence $2.77 \%$ with an exception of the dunes fixed by the natural regeneration and the dunes submitting the fixation 
influence where this spot is owned by the nanophanerophytes.

The percentage of the phanerophytes, nanophanerophytes, hemicryptophytes and geophytes decreases with xeric and openness of the environment whereas the percentage of the therophytes and the chameaphytes increases.

The numerical abundance of the therophytes indicates the openness of the vegetal rug many authors present the therophytisation as a form of resistance to the climate rigors (Negre, 1966; Barbero, 1990). We notice that the more the conditions of the environment are rigors, the more the therophytes increase whereas the phanerophytes decrease and that is what we observed during the period in which the studied area received an average rain quantity very feeble during the quarters of the first months of the year 2008. This rainfall has privileged the development of the therophytes. Consequently, we remark the deflation of the soil and silting at some spots, this silting on the self mulching permits the development of the therophytes.

Therefore in a particular mesoclimate, the rate therophytes is linked to the type of the vegetal formation and particularly to its openness degree and consequently (Daget, 1980). Indeed, the high commission of the development of the steppe (HCDS) rends the planted perimeters a month per year to farmers on basis of the state of the vegetation and the climatic condition in to enrich the soil with nitrates and permit the development of ruderals.

\section{Real spectrum}

The contribution of the biological types to the vegetal rug follows the following schema: Phanerophytes > Therophytes > Hemicryptophytes > Chameaphytes > Nanophanerophyte in the dunes fixed by $T$. gallica and $T$. aphylla (L.) Karst (Group 1). In the group of the dunes fixed by Retam retam Webb and T. aphylla (L.) Karst (Group 2) the plan becomes Phanerophytes > Nanophanerophytes > Therophytes > Chameaphytes > Hemicryptophytes $>$ Geophytes.

In the group belonging to the dunes of the natural regeneration and the dunes submitting to the influence of the fixation (Group 3): Phanerophytes > Chameaphytes > Therophytes > Hemicryptophytes. The phanerophytes are well represented with a very high rate of $69.83 \%$ in Group 1 and we also notice a high rate on $47 \%$ in Group 2. This dominance is explained by the plantation of $T$. gallica L. and T. aphylla (L.) Karst that represents important coverings.

The nanophanerophytes are well represented in Group 3 too with the rate of $34.99 \%$ whereas they are in codominance with the hemicryptophytes in Group 2 with a rate of 3.72 and $4.2 \%$, respectively in Group 1 with a rate of 13.95 and $3.84 \%$ for each one.
Le Houerou (1992) focus on the important of chameaphytes in the grasses formations and this is due to the fact that they are not grazed by the herds that prefer hemicryptophytes and therophytes. Indeed, Hemicryptophytes generally prefer the damp environment rich in organic matter (Barbero et al., 1989) which represent a feeble content in the groups and explains their weakness in the space covering.

Relative significant rates of the therophytes: $21.72 \%$ in Group 1, 12.8 \% in Group 3 and $8.09 \%$ in Group 2 was also noticed. This therophytes dominance can be explained by the presence of the productive and disrupted housing habitat were the therophytes behaved as redurals according to Grime (1977).

Finally, the geophytes of insignificant value $(<1 \%)$ in Group 2, whereas they do not exist in Groups 1 and 3, what goes back to the forest meadow formations formed by the plantation of $R$. retam Webb. that represent recovering with a rate of more than $50 \%$ on the downs and down depth of the dunes.

\section{Quantitative evaluation of the floral diversity of different groups}

The quantitative results obtained with three plants groups are presented in Table 1. If we consider only the floristic composition, we remark that the obtained results are logic; this means that the dunes anciently fixed are richer in taxons than the recently fixed and anthropised stations.

This richness was explained by self mulching effect, the highest value of Shannon weaver -index $\left(\mathrm{H}^{\prime}\right)$ was obtained in Group 1; $H^{\prime}=3.12$ which is the richest specifically with 57 species, followed by Group 3; H' = 2.61 less rich specifically with 24 species but mostly found with important abundance indexes dominance. Finally, with Group $2 \mathrm{H}^{\prime}=2.18$ which is relatively inferior to that already obtained.

The diversity index $\left(\mathrm{H}^{\prime}\right)$ can now be seen to vary with specific richness (Ramade, 1981; Lacoste and Salanon, 1999). Whereas if we consider the equitability (E) we notice that recently fixed dunes and which are under the fixation influence present relatively superior values, $\mathrm{E}=$ 0.56 than those anciently fixed by $T$. gallica L., $T$. aphylla (L.) Karst and $R$. retam Webb. $\mathrm{E}=0.53$ and $\mathrm{E}=0.41$, respectively this means that recently fixed dunes which are under the fixation present a diversity relatively less important than the fixed dunes which was explained by the fact that the silting up diminishes the floristic richness notably the number of species.

\section{Raw frequency diagrams}

The row frequency diagrams (Figure 13) obtained for the three groups show curves that generally present the same look indicating consequently a middle diversity and 
Table 1. Quantitative results of the biodiversity of three groups

\begin{tabular}{lccc}
\hline \multirow{2}{*}{ Quantitative } & \multicolumn{3}{c}{ Groups } \\
\cline { 2 - 4 } & I & II & III \\
\hline Specific diversity & 57 & 37 & 24 \\
Shannon weaver -index (H') & 3.12 & 2.18 & 2.61 \\
Equitability- index $(\mathrm{E}):$ & 0.53 & 0.41 & 0.56 \\
\hline
\end{tabular}

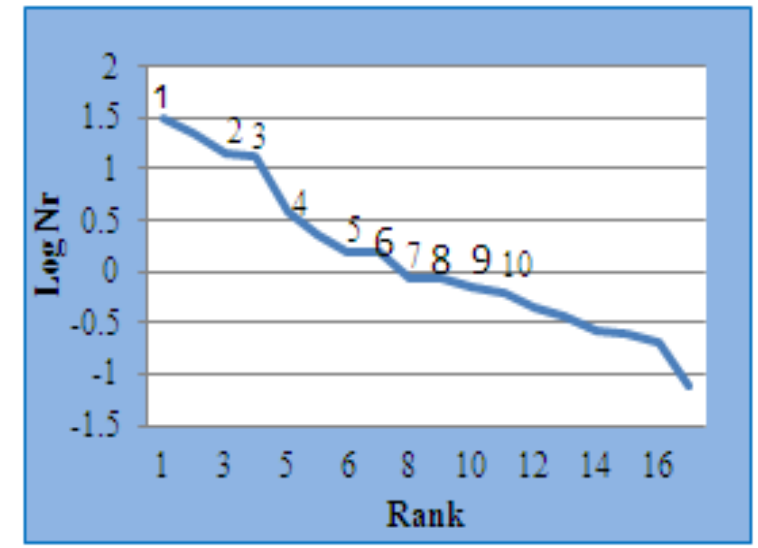

a

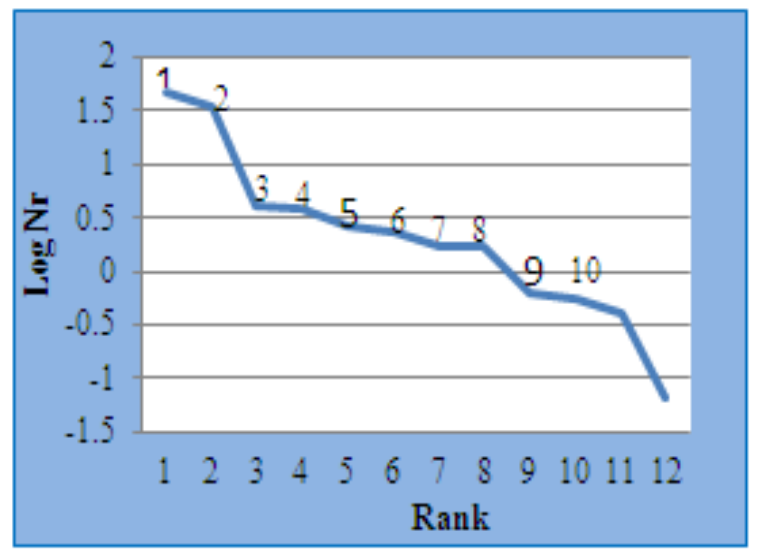

b

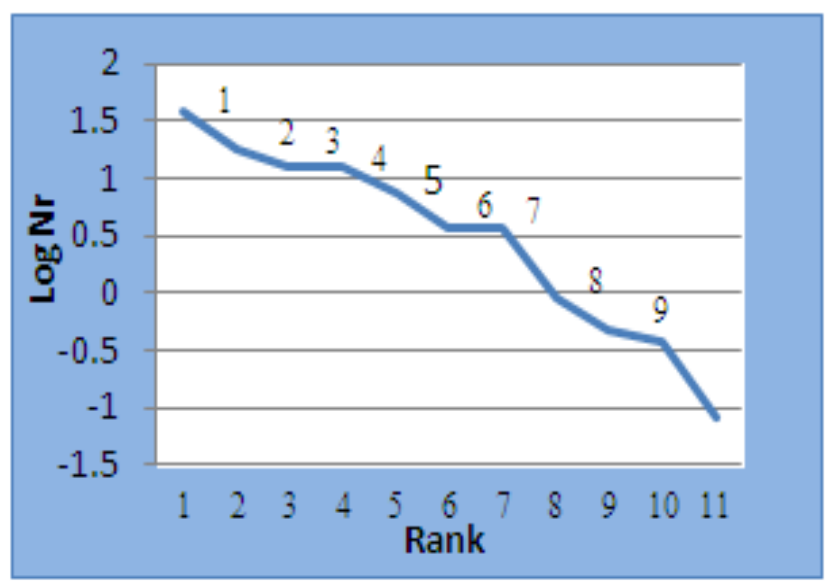

C

Figure 13. Real biological spectrum of three groups a. Diagram rank-frequency -Group I b. Diagram rankfrequency -Group II c. Diagram rank-frequency -Group III.

equitability (Frontier and Pichod-Viale, 1998) with a right extremity, a contingent of rare species.

On the dunes fixed by $T$. gallica L. and T. aphylla (L.) Karst (Figure 13a), the floral cortege is marked by the abundance of the fixating species $T$. aphylla (L.) Karst (1), T. gallica L. (2), L. arabicum (4), P. atlantica (5) as well as a remounted biologic marked by the dominance of L. rigidum (3) H. murinum (6), Loeflingia hispanica (7), helichrysum stoechas (8), P. albicans (9) and Astragalus cruciatus (10) indicate the fertility of the soil after its fixation.
In group of the dunes fixed by $R$. retam Webb. and $T$. aphylla (L.) Karst (Figure 13b) the physionomicall dominant species are principally the essence fixating $T$. aphylla (L.) Karst (1) and $R$. retam, floristic diversity formed of Plantago ovata (3) Phalaris minor (4), A. campestris (5), O. arenarium (6), $P$. albicans (7), Leontodon mulleri (8), helichrysum stoechas (9) and Leontodon hispanicus indicating a significant remounted biologic through this type of fixation.

Finally, at the level of dunes which are influenced by the fixation and regeneration of $R$. retam Webb. 
(Figure 13c), the floristic cortege is marked by the abundance of sandy plants such as $R$. retam Webb. (1), S. satureioides (2), E. guyoniana (3), A. pungens (4), Malcolmia aegyptiaca (5) P. teretifolia (6), O. natrix (7), Silene arenarioides (8) and Lotus pusillus (9).

\section{Conclusion}

The results obtained show the success of plantations through resumption of the natural vegetation and comeback biological significant. There is a lively change of the current situation of intervention by the installation of very varied vegetation modifying the surface of the ground on all the fixed dunes. The analysis of the flora of three plant groups shows that these groups have a wealth in families, genres and varied species. The group of the dunes fixed by $T$. gallica L. and T. aphylla (L.) Karst is the richest with 57 species followed by the dunes fixed with $R$. retam Webb and $T$. aphylla (L.) Karst with 36 species against 24 species in the dunes of recent natural fixation; characterized by the presence of sandy plants. The most represented families on the generic and specific plan were Astéraceae, Fabaceae and Poaceae.

On the quantitative level, the indexes diversity vary according to the specific richness were remarked. The Shannon index registered on the vegetation of the dunes fixed by $T$. gallica and $T$. aphylla (L.) Karst that is $\mathrm{H}^{\prime}=$ 3.12 , it is of 2.61 at the levels of dunes fixed by $R$. retam Webb. and T. aphylla (L.). Karst and 2.61 in the levels of dunes fixed by $R$. retam Webb. and sandy plants, consequently, this leads to quantitative and qualitative floristic richness of the palatable species notably of the therophytes which explains the augmentation of the Shannon index in the fixed and consolidated dunes.

This analysis also proved that dampness and soil stability are the ecological factors responsible of the composition and the repartition of the vegetation in the different studied dunes. The condition of the development of these species, in addition to the installation of the species show that there exists a noticeable stability of the dunes, and this is due to the mechanical and biological treatments achieved on these dunes.

\section{Conflict of Interests}

The authors have not declared any conflict of interests.

\section{ACKNOWLEDGEMENTS}

The authors acknowledge the technical support of Ecology Laboratory Bab elzzouar Houari Boumediene. The authors specially thank Senni Rachida University Ziane Achour Djelfa, Senni Zahia and Latreche Nabila for their help during labor. Special thanks go to Benlabiod
Dinidina Director of NIFR of Djelfa for all his help on the field work.

\section{REFERENCES}

Aidoud A (1983). Contribution in study of the steppes ecosystems of Sud-Oranais. Phytomasse, productivity and pastoral applications. 3rd thesis cycle. USTHB. Algiers P. 253

Barbero M (1990). Mediterranean bioclimatology, sclerophylly, sylvigenèse. Ecol. Mediterr. pp. 171-112.

Barbero M, Loisel R, Quezel P (1989). Disturbance and fires in Mediterranean region. Int. Estud. Pyrenaicos jaca 12:409-419.

Benzecri JP, Coll (1973). The Data analysis the analysis of the correspondences. Paris 2:619.

Chouial A, Hammoudi A, Makhlouf L, Tolba K (2000). Algerian Experience regarding mechanical and biological fixation of the wind formations: project of experimental research on the techniques of fight against the wind dynamics in the Algerian steppes area, ElMesrane, Djelfa., I.N.R.F. Algiers, (Appendix, 22. Tab, graph, plans, maps), photos.). Sup. 50 ha. Project of execution. P. 65.

Daget $\mathrm{Ph}$ (1980). On botanical life forms as adaptive strategy (case therophytes). In: Barbault. R, Blandin. P and Meyer.J.A. (eds), Research in theoretical ecology: adaptive strategies, Maloine, Paris pp. 89-114.

Djebaili (1984). Phytosociological research on vegetation and phytoecological high steppe plains of the Saharien Atlas. O.P.U Alger, P. 177.

Ellenberg H, Mueller-Dombois D (1967). Tentative physiognomicecological classification of plant formations of the earth Ber Geobot Inst Rubel. 37:21-55.

Frontier S (1983). The sampling of the specific variety. In Statégie of sampling Ecology, Frontier and Masson edict., Paris Coll. Ecol. 18:494.

Frontier S, Pichod-Viale D (1998). Ecosystem: structure, functioning, evolution. 2nd éd. Dunod. Paris. P. 447.

Gounot M (1969). Method of quantitative study of the vegetation. Masson and Cie, Paris. P. 314.PMid:4983515

lonesco T, Sauvage CH (1962). The types of vegetation of Morocco, attempt of naming and definition. Rev. Geogr. Morocco 1-2:75-86.

Kaabeche M (1997). Flora and vegetation in the basin Hodna. Acta Bot. Gall. 143-1:85-94.

Lacoste A, Salanon R (1999). Elements of biogeography and ecology. 2nd éd. Nathan, Paris. P. 318.

Le Houerou HN (1992). An overview of vegetation and land degradation in world arid lands. In: Dregne H.E (Ed), Degradation and restoration of arid lands,. International center for Arid and semi-arid Land Studies Texas Tech. Univ., Lubbock pp. 127-163.

Maire R (1926). Map phytogeographique of Algeria and Tunisia (Note). Gouv. Gén. Alg. Serv. Cart., Algiers: P. 78.

Makhlouf $L$ (1992). Study sedimentologic of sand of dune cordon in the ponds of Zahrez Gharbi (W.Djelfa). Thesis. Doct United by Paris VI, P. 236.

Makhlouf L, Chouial A and Ounesli R (2000).Essays of introduction of four varieties of Opuntia (spineless, lancéolata, crawling, robusta) experimental project of El-Mesrane (Djelfa). Technical note, document interns INRF.

Makhlouf $L$ (2004). Technical formation on the phenomena of blocking with sand, stabilization of dunes and their development. Summary. (OF 29/05 on 02/06/2004). I NIFR.

Negre R (1966) Les Thérophytes. Mem. Soc. Bot. France, 92-108.

Ozenda P (1977). Flora of the 2nd Sahara Ed. National Centre for Sientific Research, Paris, P. 622.

Ozenda P (1982). Vegetables in the biosphere. Doin. Ed, Paris, P. 622.

Ozenda P (1991). Flora and vegetation of Sahara. Paris, edition of the National Centre of Scientific research (National Centre for Sientific Research,), P. 662.

Pouget M (1979). The relations ground-vegetation in steppes southfrom Algiers. Univ. Aix-Marseille III. Paris. P. 466. + pl. h.t.

Pouget M (1980). Soil-Vegetation relation in the southern steppes Algiers's ORSTOM, Paris. P. 555. 
Quezel P, Santa S (1962). New flora of Algeria and Southern desert regions. PARIS (National Centre for Scientific Research) P. 1170.

Quezel P, Santa S (1963). New flora of Algeria and Southern desert regions. NCSR Paris P. 1170.

Ramade F (1981). The ecology of natural resources. Masson, Paris. P. 322.
Raunkiaer C (1934). The life from of plants and their bearing on geography. Collected. papers. Clarendon. Press. Oxford. P. 632. 